\title{
Kay Smith
}

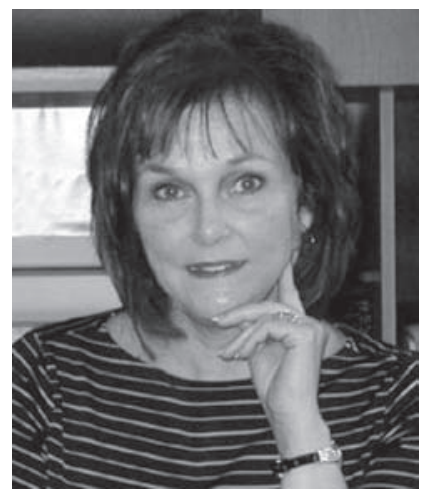

\section{The High School Connection}

\section{From Hinton to Hamlet Seeing Old Things New Again}

$\mathbf{W}$ onderful, can't-putdown books on pedagogy and literacy practice are rare, but a second edition of a wonderful, can't-putdown book on pedagogy and practice is a real treasure. In Sarah K. Herz and Donald Gallo's second, revised, and expanded edition of From Hinton to Hamlet: Building Bridges between Young Adult Literature and the Classics, teachers and parents feel invited to join a meaningful conversation which includes the need to consider stages of students' reading development; providing a "comfort level in students' reading choices," and "providing quality literature that is accessible.”

Sound interesting? Yes, it is! Learning HOW to connect teens to text is an interesting part of our craft, and yet this book offers so much more. Consider the aforementioned discussions as only the tip of the iceberg; this book is filled with new connections, new young adult literature discussions, and fresh links to new methods of instruction. Who could ask for more? Although great from its first creation, ten years have passed since this book's first publication, and in those ten years, animals have been cloned and digital music now drifts out of mini Ipods. In the ten years since the first edition of From Hinton to Hamlet, the range

As an old-hand at teaching, one who began her career when our main objective was to underline nouns and verbs, I always find it extraordinary when I am visiting schools and see old practices, such as reading and re-reading canonical texts, employed in exactly the same way they were too many years ago. and quantity of adolescent titles has also grown exponentially. With change and growth, new connections are always welcome, and here's why:

As an old-hand at teaching, one who began her career when our main objective was to underline nouns and verbs, I always find it extraordinary when I am visiting schools and see old practices, such as reading and re-reading canonical texts, employed in exactly the same way they were too many years ago. Not only does tradition still embrace the practice, but also the identical titles we read ten, twenty, and even thirty years ago. Timeless literature is a moniker that may be meaningless to our techno-savvy and active adolescents. Luckily for those who still valiantly usher young readers through the timehonored likes of The Grapes of Wrath, Great Expectations, The Great Gatsby, The Scarlet Letter, and of course, Hamlet, we can once again thank Herz and Gallo for showing us the way to couple canonical texts with an adolescent text, thereby making the read relevant and even fun. Some might 
disagree, but even the standard, the rule, the norm, the canon, and the law is not compromised when reading it becomes fun and relevant. You'll be convinced when you experience the talent and craft of Herz and Gallo.

Showing how to design "themed" connections by pairing canon with young adult literature is definitely one of this book's greatest appeals, especially to English teachers. However, with the encouragement all teachers receive to create cross-curricular units, the new and paramount appeal of this book can be found in a chapter with an interesting name: Other Backyards: Using Young Adult Literature across Other Disciplines. With that title, with the invitation for all disciplines to use young adult literature to make connections to content, this book should be on every teacher's Christmas list. Why? It's an easy consideration: A physical education teacher could make fitness memorable by assigning reading! What a novel thought, but after teen athletes finish The Basket Counts by Arnold Adoff or Tangerine by Edward Bloor, the
I especially liked Herz and Gallo's suggestions that the Westward Movement, issues of immigration, and nature and ecology could be taught as part of an interdisciplinary approach that shows "reading and writing are not the exclusive purview of English/ language arts teachers."

lessons of fitness become indelible. I especially liked Herz and Gallo's suggestions that the Westward Movement, issues of immigration, and nature and ecology could be taught as part of an interdisciplinary approach that shows "reading and writing are not the exclusive purview of English/language arts teachers."
With this wonderful second edition of From Hinton to Hamlet on our personal and library shelves, teachers will find that their content is enriched, and most importantly, that young adult literature is a bridge to comprehension and cognitive work with age-old, wise, but nevertheless prescribed texts. This book is a must-have ... and as I said before: It is a real treasure!

Kay Smith is an assistant professor of English at Utah Valley State College, in Provo, Utah. She is an alumna of Utah State and Brigham Young Universities, with degrees in English and music education, and school administration. After seventeen years as a high school teacher, principal, and college adjunct faculty, she left what she loved and decided to do what she loved even more: teaching English education on the college level. She currently teaches Young Adult Literature and Methods of Literacy at Utah Valley State College. She is married to Michael D. Smith, and they are the proud parents of seven children and proud grandparents of six. She can be reached at smithky@uvsc.edu. 